\title{
PENGARUH TIME BUDGET PRESSURE, AUDIT TENURE DAN UKURAN KAP TERHADAP KUALITAS AUDIT
}

\author{
Mohamad Alfi Amrulloh', Made Dudy Satyawan² \\ Accounting Bachelor Program Universitas Negeri Surabaya ${ }^{1}$, Accounting \\ Department Universitas Negeri Surabaya ${ }^{2}$ \\ Surabaya, Indonesia \\ mohamadalfi1234@gmail.com ${ }^{1}$, madesatyawan@unesa.ac.id ${ }^{2}$
}

\begin{abstract}
In carrying out their duties, auditors must be competence and have to maintain their audit quality to provide trust to stakeholder. However, currently there are many cases that will causes the audit quality to decline. The cases is about financial cases that are still being discussed in public and have connection about audit quality on financial statement. The objective of this study was to determine effect of Time Budget Pressure, Audit Tenure and Audit Firm Size on Audit Quality. This study uses the primary data from questionnaire that was distributed to auditor KAP in Surabaya. Method determination sample used purposive sampling criteria and have 55 sample data can used. Data analysis model is multiple linear regression analysis. The result of this study indicate time budget pressure have positive effect on audit quality, but audit tenure and audit firm size has no effect on audit quality.
\end{abstract}

Keywords : Time Budget Pressure, Audit Tenure, Audit Firm Size and Audit Quality

\section{PENDAHULUAN}

Persaingan bisnis saat ini semakin meningkat, sebanding dengan permasalahan bisnis yang meningkat pula. Seperti yang dialami beberapa perusahaan besar belakangan ini, salah satunya yaitu PT Jiwasraya. Perusahaan asuransi tertua dan terbesar di Indonesia ini pada tahun 2018 dinyatakan mengalami gagal bayar dalam memenuhi kewajiban terhadap nasabahnya. Hal ini terjadi karena kurangnya penerapan tata kelola korporat yang baik terutama dalam hal pengelolaan investasi dan mengalami kerugian hingga tidak mampu memenuhi kewajiban terhadap nasabahnya. Selain itu juga terjadi pada PT Sunprima Nusantara Pembiayaan (SNP Finance) yang merupakan perusahaan multi-finance yang menyalurkan dana dari kreditur (bank) kepada nasabahnya. Namun, pada tahun 2018 SNP Finance mengalami kredit macet hingga mengajukan Penundaan Kewajiban Pembayaran Utang (PKPU) sebesar Rp 4,07 triliun. Kedua perusahaan tersebut mengalami kegagalan dalam memenuhi kewajibannya salah satu penyebabnya yakni tidak menerapkan tata kelola korporat dengan baik. Dibuktikan kedua perusahaan tersebut memanipulasi laporan keuangannya sehingga menghilangkan prinsip transparansi dari tata kelola korporat tersebut. Menurut OECD (1999) tata kelola korporat merupakan lini sistem yang digunakan 
untuk mengendalikan kegiatan operasional perusahaan. Tata kelola korporat mengatur hak dan kewajiban dari pihak berkepentingan seperti manajemen, shareholder, dan stakeholder. Konflik kepentingan yang biasa terjadi antara pihak berkepentingan tersebut dapat teratasi jika perusahaan dapat menerapkan tata kelola korporat yang baik. Selain itu juga dapat menciptakan output yang memiliki kualitas baik juga seperti pada laporan keuangan perusahaan.

Perusahaan berkewajiban untuk menyusun laporan keuangan sesuai dengan Standar Akuntansi Keuangan (SAK) yang berlaku serta terbebas dari salah saji yang material. Untuk memenuhi itu laporan keuangan perusahaan memerlukan jasa audit atas laporan keuangan yang akan menghasilkan opini terhadap laporan keuangan. Akuntan publik dipercaya oleh masyarakat untuk memberikan opininya terhadap laporan keuangan perusahaan. Profesi akuntan publik bertugas untuk memberikan kepercayaan terhadap masyarakat mengenai kualitas informasi laporan keuangan perusahaan, memiliki sifat andal yang akan digunakan untuk dasar pengambilan keputusan (Arisinta, 2013). Hal ini membuktikan peran akuntan publik sangat penting dalam proses tata kelola perusahaan sehingga wajib menjaga kualitas auditnya agar dapat memberikan informasi yang andal kepada masyarakat.

Kualitas audit dapat terlihat ketika kondisi seorang auditor yang melaporkan ketidaksesuaian temuan audit dengan standar laporan keuangan perusahaan (DeAngelo, 1981a). Kualitas audit dari setiap KAP dapat menentukan temuan dan bukti atas ketidaksesuaian dengan laporan keuangan sehingga ketidaksesuaian tersebut dapat segera dievaluasi oleh perusahaan. KAP yang telah dipilih oleh perusahaan harus menjalankan amanah dalam menjalankan proses audit sesuai dengan perjanjian/kontrak awal yang telah disepakati.

Dalam kontrak awal perikatan tersebut terdapat jangka waktu proses audit, sehingga pihak KAP yaitu yang berkerja sebagai auditor harus menetapi jangka waktu yang diberikan tersebut. Hal ini mengharuskan auditor untuk menyusun perencanaan audit dengan melakukan anggaran waktu audit yang nantinya sebagai pedoman selama menjalankan proses audit. Akan tetapi, hal tersebut dapat memberikan time budget pressure atau tekanan anggaran waktu kepada auditor ketika menjalankan proses 
audit. Menurut (Arisinta, 2013) time budget pressure mempengaruhi kualitas audit ketika pengambilan keputusan serta pelaksanaan prosedur audit. Perencanaan waktu yang maksimal akan memberikan kualitas audit yang maksimal pula sehingga hasil audit yang diberikan juga maksimal, begitu juga sebaliknya (Ningsih, 2013).

Tekanan anggaran waktu yang tinggi dan terus-menerus akan mengakibatkan tindakan disfungsional yang sebenarnya bertujuan untuk mencapai ketepatan waktu penugasan audit. Perilaku disfungsional ditandai dengan tidak berjalannya suatu prosedur audit yang sudah direncanakan. Selain itu, ketepatan waktu menentukan kinerja auditor saat menjalankan penugasan audit. Disisi lain, tekanan anggaran waktu berpotensi meningkatkan kualitas audit dikarenakan auditor dapat menghindari informasi yang tidak relevan sehingga dapat lebih fokus terhadap informasi yang relevan (Glover,1997 dalam Mcnamara \& Liyanarachchi, 2008). Penyusunan anggaran waktu dilakukan ketika pada perencanaan audit, jika tepat maka akan menghasilkan kualitas audit yang sesuai dikarenakan auditor dapat menjalankan prosedur-prosedur audit sesuai dengan yang direncanakan ketika perencanaan audit.

H1 : Time Budget Pressure berpengaruh terhadap Kualitas Audit

Selain itu, terdapat hal lain yang dapat memberikan pengaruh kepada kualitas audit, yaitu audit tenure (masa perikatan audit). Audit tenure dapat menjadi ancaman bagi independensi auditor (Alsmairat et al., 2019). Masa perikatan yang masih singkat menyebabkan minimnya pengetahuan auditor terhadap klien, namun jika masa perikatan tersebut terlalu lama maka akan menyebabkan lunturnya independensi dari auditor tersebut (Kurniasih \& Rohman, 2014). Independensi auditor ini akan mencerminkan dari kualitas audit itu sendiri, sehingga jika independensi itu luntur dikarenakan kedekatan hubungan KAP dengan klien maka kualitas audit pun dapat menurun.

Masa awal perikatan menjadi masa yang krusial bagi auditor, dikarenakan kegagalan audit umumnya lebih tinggi pada masa awal perikatan. Masa ini menjadi langkah awal mengenal proses bisnis perusahaan bagi auditor sehingga terjadi adaptasi dalam proses audit (Arel et al , 2005 dalam Jackson et al., 2008). Proses adaptasi tersebut menjadi 
tantangan bagi auditor untuk memahami proses bisnis dari perusahaan.

Dengan berjalannya waktu, auditor semakin memahami proses bisnis dari perusahaan sehingga mengalami peningkatan kurva pembelajaran yang signifikan (Knapp , 1991 dalam Jackson et al., 2008). Oleh karena itu, pengetahuan auditor atas proses bisnis perusahaan akan menjadi lebih baik ketika telah menjalani jangka waktu yang lebih lama. Pengetahuan ini memberikan pengaruh kinerja audit dari auditor tersebut meningkat. Dengan demikian, umur masa perikatan dapat meningkatkan kualitas audit (Jackson et al., 2008).

Masa perikatan yang telah terjalin lama kemungkinan akan memberikan kepercayaan pada perusahaan, namun disisi lain akan melunturkan independensi dan objektivitas auditor (Al-Thuneibat et al., 2011). Hal ini juga dapat menghasilkan perilaku auditor yang loyal pada perusahaan sehingga kehilangan profesionalitas dalam menjalankan penugasan audit. Hal ini dapat mengakibatkan menurunya kualitas audit. Berdasarkan pemikiran yang muncul diatas menimbulkan pertanyaan empiris mengenai hubungan audit tenure dengan kualitas audit.
H2 : Audit Tenure berpengaruh terhadap Kualitas Audit

Gambar 1.

Kenaikan Sanksi KAP

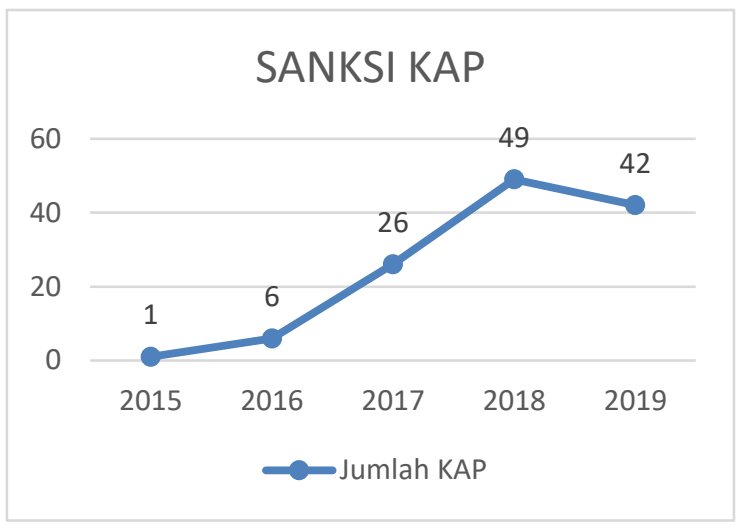

Sumber : data diolah dan diambil dari Laporan Tahunan PPPK Tahun 2017 dan 2018 serta Laporan Periodik 2019

Berdasarkan grafik diatas, menunjukkan bahwa terjadi kenaikan sanksi KAP selama tahun 2015-2019, sanksi diberikan karena KAP melakukan pelanggaran dalam menjalankan proses audit sehingga mengindikasikan bahwa terjadi penurunan kualitas audit dari KAP. Menurut DeAngelo (1981) dalam penelitiannya menyebutkan bahwa Ukuran KAP dapat mempengaruhi kualitas audit. Namun menurut Panjaitan (2014) berpendapat bahwa tidak adanya pengaruh ukuran KAP kualitas audit. Seperti halnya kasus Jiwasraya yang saat itu diaudit oleh KAP PwC yang mana 
merupakan KAP Big Four yang seharusnya kredibilitas tidak diragukan lagi. Meskipun Standar Audit sudah diterapkan ketika melakukan proses audit, akan tetapi akuntan publik tidak memberikan paragraph hal lain dengan memberikan penjelasan bahwa terjadi kejanggalan atas investasinya. Sedangkan pada kasus SNP Finance yang diaudit oleh Delloite Indonesia yang juga merupakan salah satu KAP Big Four memberikan opini audit yang tidak mencerminkan kondisi sebenarnya. Hal ini diindikasi terjadi kelalaian oleh Akuntan publik dengan kurang menerapkan prinsip kehati-hatian.

Ukuran KAP menjadi faktor yang dapat meningkatkan kredibilitas atas laporan keuangan perusahaan yang telah diaudit. KAP besar (afiliasi asing) cenderung memiliki kualitas audit yang superior didukung dengan investasi besar pada teknologi audit dan pelatihan audit sehingga dapat lebih akurat dalam mendeteksi salah saji yang material dibanding KAP kecil (non afiliasi asing) (DeAngelo, 1981a). KAP non afiliasi asing memiliki ketergantungan ekonomis terhadap perusahaan klien, karena KAP non afiliasi asing cenderung tidak memiliki klien sebanyak KAP afiliasi asing (Olsson , 2010 dalam Alsmairat et al., 2019).

Terdapat dua kunci mengapa KAP afiliasi asing lebih mandiri atau cenderung tidak memiliki ketergantungan ekonomis dengan perusahaan klien, yaitu: (1) pemisahan cabang yang menyediakan jasa audit dan non audit, (2) pendapatan yang diperoleh tidak berasal atau dipengaruhi satu klien saja (Adeniyi \& Mieseigha, 2013 dalam Alsmairat et al., 2019). Atas ketergantungan ekonomis yang dimiliki oleh KAP non afiliasi maka KAP akan lebih berkompromi pada kualitas auditnya karena mendapatkan tekanan oleh klien untuk menciptakan hasil yang sesuai dengan keinginan klien sehingga akan menurunkan kualitas audit itu sendiri. Sedangkan untuk KAP afiliasi asing cenderung mengabaikan tekanan dari klien karena tingkat ketergantungan ekonomis yang lebih kecil sehingga dapat menciptakan hasil audit yang lebih berkualitas dibanding KAP non afiliasi. Dengan demikian, timbulah pertanyaan empiris mengenai ukuran KAP memiliki hubungan dengan kualitas audit.

H3 : Ukuran KAP berpengaruh terhadap Kualitas Audit 


\section{Gambar 2. Kerangka Berpikir}

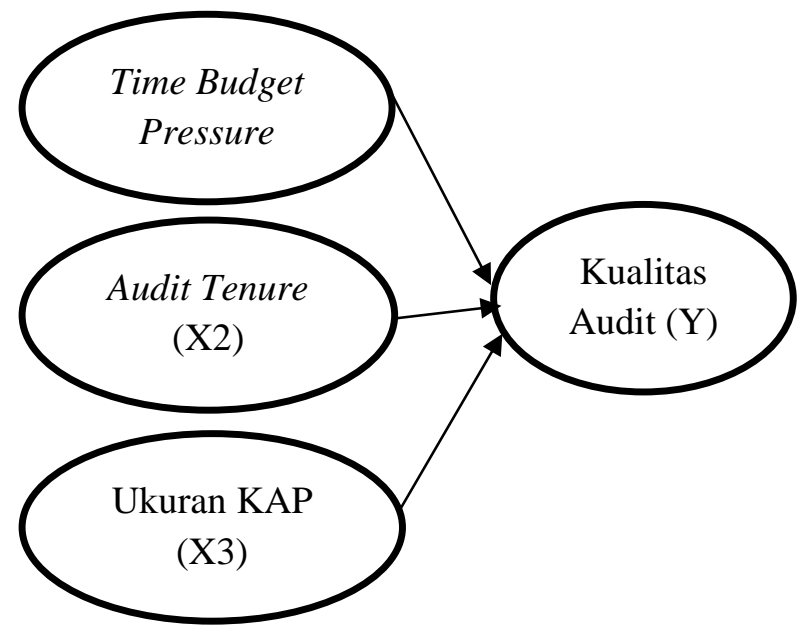

Sumber: diolah penulis

Berdasarkan uraian diatas, maka penelitian ini bertujuan untuk menguji dan mengkaji lebih jauh mengenai pengaruh ukuran KAP, audit tenure dan time budget pressure terhadap kualitas audit. Pada penelitian kali ini ditujukan pada auditor yang bekerja di Kantor Akuntan Publik di Surabaya.

\section{METODOLOGI PENELITIAN}

Penelitian ini merupakan penelitian kuantitatif. Penelitian kuanitatif mengintepretasikan fenomena dengan objektif serta berfokus pada gabungan antara logika deduktif dengan penggunaan alat-alat kuantitatif (Tan, 2008).

Data primer merupakan data yang digunakan dalam penelitian ini. Metode pengumpulan data dilakukan dengan menyebarkan kuisioner kepada auditor yang bekerja di KAP di Surabaya. Kuisioner disajikan kepada auditor dalam bentuk pernyataan dengan skala likert 5 point.

Populasi dalam penelitian ini yaitu KAP yang memiliki izin praktik di wilayah Surabaya. Persaingan bisnis KAP di wilayah Jawa Timur khususnya Surabaya menjadi fokus utama dikarenakan menjadi wilayah peringkat kedua jumlah terbanyak pemegang izin praktik akuntan publik di Indonesia setelah wilayah Jabodetabek.

Purposive sampling kriteria menjadi metode penentuan sampel yang digunakan dalam penelitian ini. Hal ini dilakukan untuk menjaga validitas dan reliabilitas data. Dengan demikian, terdapat kriteria yang menjadi penentuan sampel dalam penelitian ini yaitu:

1. Auditor bekerja di KAP yang memiliki izin praktek.

2. Auditor yang telah melakukan penugasan minimal 3 kali.

\section{Metode Analisis}

Setelah melakukan tahap pengumpulan data maka selanjutnya dilakukan tahap analisis data yang bertujuan untuk menemukan jawaban atas permasalahan yang diteliti (Muhson, 2006). Ketepatan dalam memilih teknik analisis data dapat mendukung keakuratan 
hasil penelitian. Hal ini menjadikan proses analisis data merupakan proses yang wajib dilakukan dalam penelitian. Berikut rumus dari model regresi dalam penelitian ini yaitu :

$$
Y=a+b_{1} X_{1}+b_{2} X_{2}+b_{3} X_{3}
$$

Keterangan :

Y : Kualitas Audit.

X1 : Time Budget Pressure.

X2 : Audit Tenure.

X3 : Ukuran KAP

a : Konstanta.

b : Koefisien pada masing-masing variabel independen.

Tabel 1. Indikator Variabel

\begin{tabular}{|c|c|}
\hline Variabel & Indikator \\
\hline Kualitas Audit (Y) & 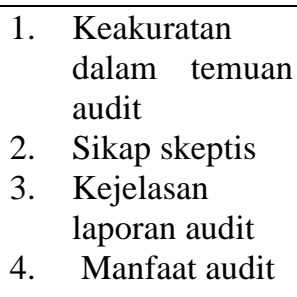 \\
\hline $\begin{array}{l}\text { Time Budget Pressure } \\
\text { (X1) }\end{array}$ & 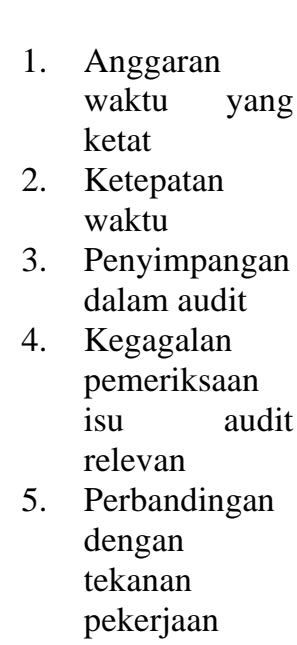 \\
\hline Audit Tenure (X2) & $\begin{array}{l}\text { 1. Jangka Waktu } \\
\text { Hubungan } \\
\text { dengan Klien }\end{array}$ \\
\hline
\end{tabular}

2. Temuan Kesalahan Klien

3. Opini Audit yang diberikan

4. Sistem Akuntansi Klien

Ukuran KAP (X3)

Variabel dummy dengan nilai 1 (Afiliasi asing) dan 0 (Non Afiliasi Asing).

Sumber : diolah penulis

\section{HASIL DAN PEMBAHASAN}

Pengumpulan data dilakukan dengan menyebar sebanyak 65 kuesioner di 14 KAP di Kota Surabaya. Namun kuesioner yang kembali dan dapat digunakan sebagai sampel sebanyak 55 butir dengan tingkat pengembalian $84,61 \%$. Responden yang bersedia ini memiliki karakteristik yang telah ditentukan peneliti melalui purposive sampling. Setelah itu, sampel tersebut dilakukan pengujian selanjutnya, seperti berikut:

\section{Uji Validitas}

Penelitian dengan pengumpulan data menggunakan kuesioner perlu dilakukan uji validitas guna mengukur kevaliditasan instrumen pernyataan pada setiap kuesioner. Berikut hasil dari uji validitas menggunakan SPSS 24: 
Tabel 4. Hasil Uji Validitas

\begin{tabular}{ccccc}
\hline Item & $\begin{array}{c}\text { Total } \\
\text { Korelasi } \\
\text { Item }\end{array}$ & $\begin{array}{c}\mathbf{R} \\
\text { Tabel }\end{array}$ & Keterangan \\
& 1 &, 558 & & \\
& 2 &, 343 & & \\
$\mathrm{X} 1$ & 3 &, 799 & & \\
& 4 &, 867 & & \\
& 5 &, 796 & & \\
& 1 &, 558 & & \\
& 2 &, 460 & & \\
$\mathrm{X} 2$ & 3 &, 531 &, 2656 & Valid \\
& 4 &, 662 & & \\
& 5 &, 674 & & \\
& 1 &, 691 & & \\
& 2 &, 680 & & \\
$\mathrm{Y}$ & 3 &, 627 & & \\
& 4 &, 530 & & \\
& 5 &, 689 & & \\
\hline
\end{tabular}

Sumber : data primer, diolah dengan SPSS 24

Pengujian ini membandingkan nilai $r$ hitung dengan $r$ tabel. Untuk nilai $r$ tabel dengan sampel 55 dan tingkat signifikansi 0,05 pada penelitian ini didapatkan dengan $(d f)=\mathrm{n}-2$ yaitu $\mathrm{r}(55-$ $2=53)=0,2656$. Syarat data dinilai valid yaitu jika nilai $r$ hitung $>r$ tabel.

\section{Uji Reliabilitas}

Kuesioner penelitian harus dilakukan uji reliabilitas sebagai syarat untuk data dapat dikatakan reliabel atau handal. Menurut Widiyanto (2010) dalam bukunya menyebutkan bahwa data dinilai reliabel jika nilai Cronbach Alpha > r tabel. Maka data penelitian ini dapat dikatakan reliabel sebagai berikut:
Tabel 5. Hasil Uji Reliabilitas

\begin{tabular}{cccc}
\hline Variabel & $\begin{array}{c}\text { Nilai } \\
\text { Cronbach } \\
\text { Alpha }\end{array}$ & $\begin{array}{c}\mathbf{R} \\
\text { Tabel }\end{array}$ & Keterangan \\
\hline X1 &, 732 & & \\
X2 &, 468 &, 2656 & Reliabel \\
Y &, 635 & & \\
\hline
\end{tabular}

Sumber : data primer, diolah dengan SPSS 24

\section{Uji Normalitas}

Teknik pengujian One-Sample Kolmogorov Smirnov (1-Sample K-S) menjadi teknik yang digunakan dalam pengujian normalitas untuk penelitian ini. Dengan syarat data dikatakan normal jika nilai signifikansi $(\mathrm{Sig})>0,05$.

Tabel 6. Hasil Uji One Sample K-S

\begin{tabular}{|c|c|}
\hline Onc & $\begin{array}{l}\text { K-S Test } \\
\text { Unstandardized } \\
\text { Residual }\end{array}$ \\
\hline$N$ & 55 \\
\hline $\begin{array}{l}\text { Asymp. Sig. (2- } \\
\text { tailed) }\end{array}$ & 200, \\
\hline
\end{tabular}

Sumber : data primer diolah dengan SPSS 24

Hasil uji 1-sampel K-S yang dilakukan menunjukkan nilai Signifikansi 0,200 > 0,05 sehingga data telah terdistribusi normal.

\section{Uji Multikolinieritas}

Uji multikolinearitas berfungsi sebagai teknik uji yang mengetahui model regresi terdapat situasi hubungan 
(korelasi) kuat antara variabel independen satu dengan lainnya atau tidak.

\section{Tabel 7. Hasil Uji}

Multikolinearitas

\begin{tabular}{cccc}
\hline Model & \multicolumn{2}{c}{$\begin{array}{c}\text { Coefficients }^{\boldsymbol{a}} \\
\text { Collinearity Statistics } \\
\text { Tolerance }\end{array}$} \\
\hline 1 & & VIF \\
\hline & & & \\
& X1 & 970 & 1,031 \\
& X2 &, 956 & 1,046 \\
X3 &, 986 & 1,014 \\
\hline
\end{tabular}

Sumber : data diolah peneliti dengan SPSS 24

Hasil uji diatas menunjukkan nilai tolerance X1 yaitu $0,970>0,10, \mathrm{X} 2$ senilai 0,956>0,10 dan X3 senilai 0,986 $>0,10$. Sedangkan untuk nilai VIF X1 yaitu $1,031<10,00, \mathrm{X} 2$ yaitu $1,046<$ 10,00 dan X3 yaitu $1,014<10,00$ sehingga model regresi dinilai terbebas dari masalah multikolinearitas

\section{Uji Heterokedastisitas}

Uji heterokedastisitas berfungsi untuk mengetahui ketikasamaan varian dari residual model regresi atau tidak. Model regresi harus terbebas dari masalah heterokedastisitas atau model yang homogen. Teknik untuk menguji masalah ini yaitu dengan menggunakan Uji Glejser.

Tabel 8. Hasil Uji Heterokedastisitas

\begin{tabular}{llrrrrr}
\hline \multicolumn{1}{l}{ Model } & \multicolumn{1}{c}{ B } & Std. Error & $\begin{array}{c}\text { Std. Error } \\
\text { Beta }\end{array}$ & \multicolumn{1}{c}{ T } & \multicolumn{1}{c}{ Sig. } \\
\hline 1 & (Constant) &,- 769 & 1,292 & &,- 595 &, 554 \\
& X1 &, 048 &, 054 &, 121 &, 892 &, 377 \\
& X2 &, 110 &, 062 &, 241 & 1,759 &, 085 \\
& X3 &,- 116 &, 397 &,- 039 &,- 293 &, 771 \\
\hline
\end{tabular}

Sumber: data diolah peneliti menggunakan SPSS 24

Hasil yang didapatkan dari Uji

Glejser yaitu menunjukkan nilai Signifikansi X1, X2 dan X3 sebesar 0,377 $>0,05,0,085>0,05$ dan $0,771>0,05$. Dapat disimpulkan model regresi terbebas dari masalah heterokedastisitas. 


\section{ANALISIS REGRESI LINEAR BERGANDA}

\section{Uji T Parsial}

Uji t parsial menjadi uji pengaruh dalam model regresi. Berikut merupakan

rumus dari model regresi dari pengujian $\mathrm{t}$ parsial:

Tabel 9. Hasil Uji T Parsial

\begin{tabular}{ccccccc}
\hline & Model & \multicolumn{2}{c}{ Unstandarized } & Standarized & T & Sig. \\
& & $\boldsymbol{B}$ & Std. Error & Beta & & \\
\hline 1 & (Constan) & 8,261 & 2,382 & & 3,468 &, 001 \\
X1 &, 382 &, 099 &, 459 & 3,843 &, 000 \\
& X2 &, 212 &, 115 &, 222 & 1,847 &, 071 \\
& X3 &,- 019 &, 732 &,- 003 &,- 026 &, 979 \\
\hline
\end{tabular}

Sumber: data diolah peneliti menggunakan SPSS 24

$\mathrm{Y}=8,261+0,382 \mathrm{X} 1+0,212 \mathrm{X} 2-0,19 \mathrm{X} 3$

1. Berdasarkan tabel tersebut didapatkan koefisien konstanta sebesar 8,261. Berarti jika Time Budget Pressure (X1), Audit Tenure (X2) dan Ukuran KAP (X3) konstan pada angka 0 (nol) maka variabel Kualitas Audit (Y) sebesar 8,261.

2. Berdasarkan pengujian model regresi menunjukkan nilai t variabel X1 (Time Budget Pressure) sebesar 3,843 dan nilai signifikansi sebesar $0,000<0,05$. Sehingga H1 diterima atau dalam artian Time Budget Pressure (X1) secara statistik parsial berpengaruh terhadap Kualitas Audit (Y). Dengan nilai Beta 0,382 yang berarti memiliki pengaruh positif.
3. Berdasarkan pengujian model regresi menunjukkan variabel X2 (Audit Tenure) memiliki nilai $\mathrm{T}$ sebesar 1,847 dan nilai signifikansi sebesar $0,071>0,05$. Sehingga dapat disimpulkan $\mathrm{H} 2$ ditolak dalam artian Audit Tenure (X2) secara statistik parsial tidak berpengaruh terhadap Kualitas Audit (Y).

4. Berdasarkan pengujian model regresi menunjukkan nilai t variabel X3 (Ukuran KAP) sebesar -0,26 dengan nilai signifikansi sebesar $0,979>0,05$. Sehingga dapat disimpulkan $\mathrm{H} 3$ ditolak dalam artian Ukuran KAP (X3) secara statistik parsial tidak memiliki pengaruh terhadap Kualitas Audit (Y), dengan nilai probabilitas $-0,19$. 


\section{Uji F Simultan}

Tabel 10. Hasil Uji F Simultan

\begin{tabular}{|c|c|c|c|c|c|c|}
\hline & \multicolumn{6}{|c|}{ ANOVA $^{a}$} \\
\hline & Model & $\begin{array}{l}\text { Sum of } \\
\text { Squares }\end{array}$ & $D f$ & $\begin{array}{c}\text { Mean } \\
\text { Square }\end{array}$ & $F$ & Sig. \\
\hline \multirow[t]{3}{*}{1} & Regression & 117,739 & 3 & 39,246 & 7,123 &, $000^{\mathrm{b}}$ \\
\hline & Residual & 280,988 & 51 & 5,510 & & \\
\hline & Total & 398,727 & 54 & & & \\
\hline
\end{tabular}

Sumber : data diolah peneliti dengan SPSS 24.

Pengujian ini membandingkan antara nilai $\mathrm{F}$ hitung dengan $\mathrm{F}$ tabel. Dengan tingkat signifikansi 0,05 serta nilai $\mathrm{f}$ tabel $(3 ; 55-$ $3)=(3 ; 52)$ didapatkan nilai $\mathrm{F}$ sebesar 2,78. Tabel diatas menunjukkan nilai $\mathrm{F}$ sebesar 7,123 dengan nilai signifikansi 0,000 sehingga didapatkan bahwa nilai F Hitung $7,123>2,78$ serta nilai signifikansi $0,000<$ 0,05. Maka artinya secara simultan variabel Time budget pressure, Audit Tenure dan Ukuran KAP memiliki pengaruh terhadap variabel Kualitas Audit.

\section{Uji Koefisien Determinasi ( $R$ Square)}

Fungsi uji $R$ Square yaitu menilai kepasitas model regresi dalam menjelaskan variabel dependen. Dengan kata lain melihat besaran kontribusi pengaruh dari model regresi tersebut.
Tabel 11. Hasil Uji Koefisien Determinasi Model Summary

\begin{tabular}{lcrrr}
\hline Model & $\mathbf{R}$ & $\begin{array}{c}\boldsymbol{R} \\
\text { Square }\end{array}$ & $\begin{array}{c}\text { Adjusted } \\
\boldsymbol{R} \text { Square }\end{array}$ & $\begin{array}{c}\text { Std. Error } \\
\text { of the } \\
\text { Estimate }\end{array}$ \\
\hline 1 &, 543 &, 295 &, 254 & 2,347
\end{tabular}

Sumber : data diolah peneliti dengan SPSS 24

Pada tabel hasil uji diatas didapatkan nilai R Square sebesar 0,295 atau 29,5\%. Berarti terdapat pengaruh variabel independent terhadap variabel dependen yaitu kualitas audit sebesar $29,5 \%$. Untuk sisanya $70,5 \%(100 \%-29,5 \%)$ dapat dijelaskan oleh variabel lain diluar dari penelitian.

\section{Pengaruh Time Budget Pressure} Terhadap Kualitas Audit

Berdasarkan pengujian model regresi melalui analisis regresi linear berganda diatas, untuk variabel time budget pressure didapatkan nilai signifikansi 0,000 dengan nilai beta 0,382 yang berarti bahwa variabel time budget pressure berpengaruh positif terhadap kualitas audit. Hasil penelitian tersebut selaras dengan penelitian Arisinta (2013) yang menyatakan bahwa time budget pressure dapat meningkatkan kualitas audit yang dilakukan oleh auditor.

Keterbatasan waktu seringkali membuat auditor lengah dalam menjalankan prosedur auditnya, bahkan menghilangkan 
prosedur yang dapat menurunkan kualitas audit itu sendiri seperti dalam penelitian (Ningsih, 2013) namun dalam penelitian ini memiliki perbedaan hasil penelitian yang justru adanya time budget pressure dapat meningkatkan kualitas audit. Dikarenakan ketika auditor menjumpai time budget pressure maka auditor bertindak lebih taktis dalam memilih prosedur yang akan dijalankan sehingga meningkatkan efektifitas dan efisiensi untuk mendapatkan kualitas audit yang maksimal. Hal ini selaras dengan teori dari (DeZoort \& Lord, 1997) yang menyebutkan bahwa auditor yang mengalami time budget pressure memiliki dua kemungkinan dalam menyikapinya, yaitu : (1) meningkatkan kinerja dengan memaksimalkan professional judgement mereka serta berfokus pada informasi yang relevan dan mengabaikan informasi yang tidak relevan atau (2) melakukan respon yang disfungsional sehingga menyebabkan premature sign-off (keputusan terburuburu).

Jika dilihat dari hasil uji penelitian yang dilakukan didapat pada indikator kuesioner terkait ketepatan waktu yang memiliki nilai rata-rata 4,29 menunjukkan bahwa responden setuju ketika menjalankan penugasan audit mereka dituntut untuk menyelesaikannya dengan tepat waktu sesuai pada kesepakatan dengan klien saat masa pra perikatan. Selain itu, pada indikator kegagalan pemeriksaan isu relevan memiliki nilai rata-rata 3,02 sehingga disimpulkan auditor meningkatkan professional judgement untuk efisiensi waktu dalam pemeriksaan isu yang relevan sehingga dalam menyelesaikan penugasan audit dapat tepat waktu serta semua unsurunsur laporan keuangan dapat di audit secara menyeluruh. Hal ini memberikan fungsi audit atas laporan keuangan dapat digunakan dalam pengambilan keputusan perusahaan yaitu seperti pada teori lending credibility menyebutkan bahwa laporan keuangan yang dipublikasikan kepada pemangku kepentingan yaitu laporan keuangan yang kredibel dan tidak terdapat salah saji yang material (Ittonen, 2010). Sehingga informasi keuangan yang nantinya berguna dalam pengambilan keputusan dapat dipertanggungjawabkan dan memperoleh manfaat bagi pengguna laporan keuangan.

\section{Pengaruh Audit Tenure Terhadap Kualitas Audit}

Berdasarkan pengujian model regresi yang telah dilakukan, didapatkan nilai signifikansi untuk variabel audit tenure sebesar 0,071 sehingga audit tenure tidak berpengaruh terhadap kualitas audit. Hal ini disebabkan lama hubungan auditor dengan klien tidak mempengaruhi kinerja mereka sehingga kualitas audit tetap terjaga. Hasil ini selaras dengan penelitian (Triani \& 
Yanthi, 2020). Hal ini dikarenakan setiap KAP telah melakukan rotasi auditor sesuai dengan peraturan POJK NOMOR 13 /POJK.03/2017 yang mewajibkan rotasi selama 3 tahun sekali untuk menjaga agar tidak terjadinya kedekatan hubungan antara auditor dengan klien sehingga tidak melunturkan independensi dan obyektifitas ketika melakukan penugasan audit.

Selain itu, terdapat peraturan pemerintah yang mengatur terkait masa perikatan praktik akuntan publik yaitu PP No 20 Tahun 2015 tentang Praktik Akuntan Publik yang menyebutkan dalam Bab V pasal 11 mengenai pembatasan jasa audit yang diberikan oleh akuntan publik berturut-turut maksimal 5 tahun buku. Setelah itu, jasa audit dapat dilakukan lagi pada laporan keuangan historis klien ketika melewati 2 tahun buku pelaporan. Berkaitan dengan aturan tersebut, pemerintah telah mengatur dalam upaya menjaga kualitas dari audit itu sendiri. Hal ini telah tercerminkan pada hasil penelitian ini karena pada masing-masing masa perikatan telah sesuai dengan aturan yang telah ditetapkan pemerintah. Selain itu, dari sisi auditor itu sendiri mereka menyadari bahwa kualitas audit tetap harus dijaga. Dalam artian hasil atas audit laporan keuangan itu sendiri merupakan hasil yang sesuai dengan kondisi nyata perusahaan. Hal ini dapat dilihat pada hasil instrumen pernyataan kuesioner pada indikator berikut:

Tabel 12. Rata-rata Indikator Audit Tenure

\begin{tabular}{clc}
\hline No & \multicolumn{1}{c}{ Indikator } & Rata-rata \\
\hline P1 & $\begin{array}{l}\text { Lamanya hubungan } \\
\text { dengan klien }\end{array}$ & 2,6 \\
P2 & $\begin{array}{l}\text { Upaya dalam } \\
\text { menjaga hubungan }\end{array}$ & 3,98 \\
P3 & $\begin{array}{l}\text { Temuan yang } \\
\text { dilaporkan }\end{array}$ & 2,11 \\
P4 & Pertimbangan audit & 4,01 \\
P5 & $\begin{array}{l}\text { Koreksi sistem } \\
\text { akuntansi klien }\end{array}$ & 4 \\
\hline & Sumber : data primer diolah peneliti
\end{tabular}

Hasil diatas menunjukkan bahwa:

1. Responden berpandangan bahwa lamanya hubungan dengan klien tidak akan memberikan pengaruh atas keputusan auditor dalam mengaudit laporan keuangan klien.

2. Responden setuju tetap akan bersifat independent meskipun telah menjalin hubungan lebih dari 3 tahun sehingga lamanya masa perikatan tidak terdapat pengaruh.

3. Responden tidak setuju dengan pernyataan tersebut. Mereka akan tetap melaporkan temuan mereka meskipun telah manjalani masa perikatan 3 tahun berturut-turut.

4. Responden setuju bahwa mereka akan tetap melakukan pertimbangan audit mereka tanpa memperhatikan hubungan dengan klien.

5. Responden tetap akan melaporkan hasil audit sesuai dengan kondisi yang 
sebenarnya tanpa memperhatikan lamanya hubungan dengan klien.

Atas beberapa pernyataan diatas dapat dikatakan rata-rata responden memiliki pandangan bahwa umur hubungan/masa perikatan dengan klien tidak akan mengurangi kualitas audit mereka. Selain itu, hal ini berhubungan dengan teori agensi yang mana auditor sebagai penengah atas konflik kepentingan antara principal dengan agent. Auditor tidak akan memihak pada kepada kedua belah pihak tersebut agar menghasilkan laporan keuangan yang obyektif. Laporan keuangan sebagai wujud transparansi informasi keuangan untuk memenuhi tata kelola yang baik yang nantinya digunakan oleh para pemangku kepentingan dalam setiap pengambilan keputusan mereka.

\section{Pengaruh Ukuran KAP Terhadap} Kualitas Audit

Hasil pengujian yang telah dilakukan menunjukkan bahwa nilai signifikansi untuk variabel Ukuran KAP sebesar 0,979 berarti tidak adanya pengaruh antara ukuran KAP dengan kualitas audit. Dalam artian kedua jenis KAP yaitu : KAP Afiliasi Asing maupun KAP Non Afiliasi dapat menjaga kualitas auditnya. Hasil ini selaras dengan penelitian terdahulu yaitu penelitian (Panjaitan, 2014) yang menyebutkan bahwa KAP yang berafiliasi asing tidak selalu memberikan kualitas audit lebih baik dari pada KAP non afiliasi.

Dalam artian seluruh KAP telah menerapkan sistem pengendalian mutu yang baik sehingga kualitas audit dapat tetap terjaga. SA 220 telah mengatur SPM yang telah disusun oleh IAPI diwajibkan untuk seluruh KAP yang berpraktik di Indonesia sehingga terdapat standar yang sama baik itu KAP Afiliasi Asing maupun Non Afiliasi Asing. Selain itu, stigma KAP yang berafiliasi asing lebih kredibel dibanding non afiliasi asing telah bergeser. KAP afiliasi asing digunakan oleh KAP hanya untuk meningkatkan branding mereka untuk klien agar kredibilitas dapat meningkat namun belum tentu dengan kualitas yang diberikan. Dalam artian untuk meningkatkan branding akan tetapi dari segi SDM, auditor tidak mendapatkan pelatihan khusus yang dilakukan oleh KAP Asing mereka. Jikalau ada, itu hanya untuk para petingginya saja bukan untuk keseluruhan auditor. Sehingga dari segi pelatihan SDM tidak ada perbedaan signifikan dibanding KAP non afiliasi asing. Mereka telah meningkatkan kualitas dari setiap auditornya sehingga dapat bersaing dalam mencari klien. Terdapat perbedaan pada hasil penelitian ini dengan prinsip yang diangkat oleh (DeAngelo, 1981) yang menyebutkan bahwa kualitas audit dapat dipengaruhi oleh ukuran dari KAP itu 
sendiri. Selain itu, Ketergantungan ekonomis seperti yang disebutkan dalam penelitian (Al-Thuneibat et al., 2011) KAP non afiliasi asing terhadap klien telah berkurang sehingga KAP non afiliasi asing dapat memberikan informasi yang relevan (baik maupun buruk) tentunya tanpa takut kehilangan klien.

Pada faktanya, seperti kasus SNP Finance yang mana diaudit oleh KAP berafiliasi asing mereka tetap tersandung kasus terkait rekayasa laporan keuangan. Serta opini yang diterbitkan tidak sesuai dengan kondisi keuangan nyata perusahaan. Atas kasus tersebut KAP Delloite Indonesia diberikan sanksi pembekuan terhadap akuntan publik yang mengaudit laporan keuangan SNP Finance tersebut. Selain itu, auditor tidak sama sekali mengeluarkan opini going concern padahal kenyataanya terdapat dugaan akan terjadi kredit macet jika dilihat dari likuiditas perusahaannya. Dengan demikian, tidak adanya jaminan kualitas audit KAP yang berafiliasi asing masih dapat tersandung kasus yang justru dengan nilai kerugian yang lebih besar. Sedangkan untuk KAP yang tidak berafiliasi asing pun belum tentu mencerminkan kualitas audit yang menurun dikarenakan mereka tetap akan menjaga kualitasnya untuk menambah nilai dari kinerja audit mereka yang berguna dalam proses mendapatkan klien.

\section{SIMPULAN}

Berdasarkan hasil uji hipotesis yang dilakukan dalam penelitian ini dengan menggunakan analisis regresi linear berganda didapatkan bahwa Time Budget Pressure memiliki pengaruh positif terhadap Kualitas Audit. Sedangkan, untuk Audit Tenure dan Ukuran KAP tidak memiliki pengaruh terhadap Kualitas Audit.

Namun disisi lain penelitian ini memiliki keterbatasan dan kekurangan yaitu tingkat pengembalian kuesioner tidak sesuai dengan target peneliti. Hal ini disebabkan kondisi pandemi yang membatasi peneliti untuk langsung bertemu dengan responden untuk memastikan pengisian kuesioner sehingga menghindari data kuesioner yang tidak terpakai. Adapun saran untuk para peneliti selanjutnya jika dilihat dari kekurangan dalam penelitian yaitu menyusun strategi pengumpulan data yang lebih efisien dan efektif sehingga dapat meminimalisir kuesioner yang tidak terisi atau data yang tidak dapat terpakai. Selain itu, memastikan responden untuk mengisi kuesioner dengan benar sesuai dengan target penelitian.

\section{DAFTAR PUSTAKA}

Al-Thuneibat, A. A., Al Issa, R. T. I., \& Ata Baker, R. A. (2011). Do audit tenure and firm size contribute to audit quality?: Empirical evidence from Jordan. Managerial Auditing Journal, 26(4), 317-334. https://doi.org/10.1108/026869011111 


\section{8}

Alsmairat, Y. Y., Yusoff, W. S., \& Ali, M. A. (2019). The effect of Audit Tenure and Audit Firm Size on the Audit Quality: Evidence From Jordanian Auditors. International Journal of Business and Technopreneurship, 9(1), $15-24$.

Arisinta, O. (2013). Pengaruh Kompetensi, Independensi, Time Budget Pressure, dan Audit Fee terhadap Kualitas Audit pada Kantor Akuntan Publik di Surabaya. Jurnal Ekonomi Dan Bisnis, 3, 266-278.

DeAngelo, L. E. (1981a). Auditor size and audit fees. Journal of Accounting and Economics, 3(May), 183-199.

DeAngelo, L. E. (1981b). Auditor size and audit quality. Journal of Accounting and Economics. https://doi.org/10.1016/01654101(81)90002-1

DeZoort, F. T., \& Lord, A. T. (1997). A Review and Synthesis of Pressure Effects Research in Accounting. Journal of Accounting Literature, 16, 28-86.

Ittonen, K. I. M. (2010). A Theoretical Examination of the Role of Auditing and the Relevance of Audit Reports. Business Administration, 28, 1-70.

Jackson, A. B., Roebuck, P., \& Moldrich, M. (2008). Mandatory audit firm rotation and audit quality. Managerial Auditing Journal, 23(5), 420-437. https://doi.org/10.1108/026869008108 75271

Kurniasih, M., \& Rohman, A. (2014). Analisis Faktor-Faktor Yang Mempengaruhi Thin Capitalization Pada Perusahaan Multinasional Di Indonesia. Diponegoro Journal of Accounting, O(0), 652-660.

Mcnamara, S. M., \& Liyanarachchi, G. A. (2008). Time budget pressure and auditor dysfunctional behaviour within an occupational stress model. Accountancy Business and the Public Interest, 7(1), 1-43.
Muhson, A. (2006). Teknik Analisis Kuantitatif. Makalah Teknik Analisis II, 1-7. http://staffnew.uny.ac.id/upload/13223 2818/pendidikan/Analisis+Kuantitatif. pdf

Ningsih, A. . P. R. C. (2013). Pengaruh Kompetensi, Independensi, dan Time Budget Pressure terhadap Kualitas Audit. E-Jurnal Akuntansi Universitas Udayana, 4(1), 92-109.

OECD. (1999). OECD Principles of Corporate Governance Organisation For Economic Co-Operation And Development Organisation For Economic Co-Operation And Development. Meeting of the OECD Council at Ministerial Level, 1 of 46.

Panjaitan, C. M. (2014). Pengaruh Tenure, Ukuran Kap Dan Spesialisasi Auditor Terhadap Kualitas Audit. Diponegoro Journal of Accounting, O(0), 221-232.

Tan, S. E. S. H. Y. (2008). Metode penelitian akuntansi: mengungkap fenomena dengan pendekatan kuantitaif dan kualitatif (p. 108).

Triani, N. N. A., \& Yanthi, M. D. (2020). The Effect Of Audit Firms Size, Leverage, Going Concern Opinion, Audit Tenure, on Audit Quality in Indonesia. Business and Management Research, 144(3), 261-265. https://doi.org/10.37641/jiakes.v8i3.39 1

Widiyanto, J. (2010). SPSS For Windows Untuk Analisis Data Statistik dan Penelitian. BP - FKIP UMS. 